Mohammed M.Sadoon BDS.MSc. (Lect.)

\section{Effect Of Surface Treatment on Shear Bond Strength of Acrylic Resin to Cobalt-Chromium Alloy}

\author{
Department of Prosthetic Dentistry
}

College of Dentistry, University of Mosul

$$
\begin{aligned}
& \text { الخلاصة } \\
& \text { الأهداف : تمدف هذا البحث لتقييم تأثير مادة التمهيدية للمعدن مع تأثير الحامض،و شعاع الليزر، والرمل التفجيري على قوة السندات القص ( SBS ) وخشونة }
\end{aligned}
$$

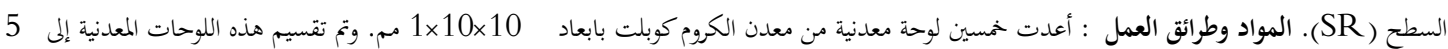

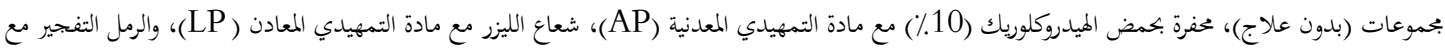

$$
\begin{aligned}
& \text { مادة التمهيدي المعادن ( SP)، و التمهيدي المعدن وحده (P)). تم اختبار هذه الجماعات لقوة السندات القص وخشونة السطح. النتائج : هناك فروق ذات دلالة } \\
& \text { إحصائية في قوة السندات القص من جميع البحموعات المعالجة على النقيض من سيطرة الجماعات، وكان AP أعلى القص قيمة قوة السندات. بينما خشونة السطح }
\end{aligned}
$$

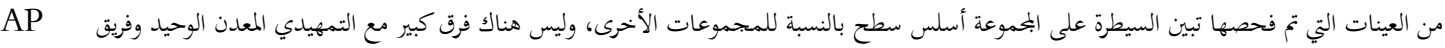

$$
\begin{aligned}
& \text { كان أعلى الأسطح خشونة. الاستنتاجات : التمهيدي المعدن يحسن قوة الرابطة بين كوبلت الكروميوم و راتنجالاكريليك المتصلب كيمائيا للاسطحالمعلاجة مع برع }
\end{aligned}
$$

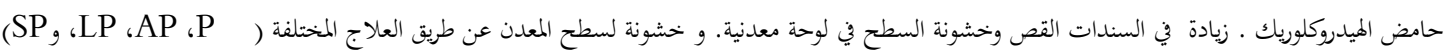

$$
\begin{aligned}
& \text { تطوير SBS من السندات المعدنية لراتنج. }
\end{aligned}
$$

\title{
ABSTRACT
}

Aims: to evaluate the effect of metal primer with acid etch, laser beam, and sand blasting on shear bond strength(SBS) or resin metal and surface roughness(SR). Materials and methods: fifty Co-Cr metal plate were prepared with 10X10X1 mm dimensions. These metal plates were divided in to 5 groups control (without treatment), acid etched with hydrochloric acid(10\%) with metal primer(AP), laser beam with metal primer(LP), sand blasting with metal primer(SP), and metal primer alone(P). These groups were tested for shear bond strength of resin to metal and surface roughness. Results: there are a significant differences in shear bond strength of all treated groups in contrast to control groups, and the AP had the highest shear bond strength value. While surface roughness of tested samples shows the control group smoothest surface in relation to other groups and there is no significant difference with metal primer only and the AP group had higher surfaces roughness. Conclusion: metal primer improve bond strength between $\mathrm{Co}-\mathrm{Cr}$ and chemical cured acrylic resin, the treating surface with HCL acid increase SBS and SR of metal plate. The roughening of metal surface by different treatment ( $\mathrm{P}, \mathrm{AP}, \mathrm{LP}$, and SP) improve the SBS of metal bond to resin.

Key words: Metal primer, Shear bond strength, surface roughness, Co-Cr.

Sadoon MM, Effect Of Surface Treatment on Shear Bond Strength of Acrylic Resin to CobaltChromium Alloy. Al-Rafidain Dent J. 2014; 14(2):252-258.

Received: 26/5/2013 Sent to Referees: 27/5/2013 Accepted for Publication:5/6/2013

\section{INTRODUCTION}

In prosthodontics, the attachment of a resin matrix to a metal framework may pose significant difficulties. ${ }^{(1)}$ Acrylicresin bases are attached to the partial denture framework by means of a minor connector designed (nail head, mesh, and laderlike )so that a space exists between the framework and the underlying tissues of the residual ridge. The minimal inter ridge space may compromise denture base space which lead to breakge or spration, this separation that occurs between the acrylic- resin and the metal can eventually lead to some loosening of the acrylic resin base. ${ }^{(2)}$

Additions to a removable partial denture are usually simply made when the bases are made of resin. The addition of teeth to metal bases is more complex and necessitates casting a new component and attaching it by soldering or creating retentive elements for the attachment of a resin extension. ${ }^{(2)}$

A variety of methods are available to bond resin materials to prosthetic alloys. Bonding systems may be categorized as 
mechanical, chemical, or a combination of the two. Mechanical systems include the use of retentive mesh, loops, or beads, sometimes aided by etching and/or sandblasting. ${ }^{(3,4)}$

Jemt $^{(5)}$ reported frequent resin-metal bond failures during the first year after insertion. Jacobson ${ }^{(2)}$ noted that differences in coefficient of thermal expansion between the resin and the alloy potentiated gap formation and adverse soft tissue reactions.

The bond strength of the resin-metal interface of a prosthesis is a key factor in determining the serviceability of that prosthesis. Separation of the resin from the metal due to a compromised or weak bond can lead to microleakage, discoloration and total separation of the resin from the metal. ${ }^{(6)}$

Micromechanical retentive elements and chemical bonding systems purport to decrease the necessity for macro mechanical retention. They offer the advantage of reduced impingement of the metal framework on the resin matrix; with the increased bulk of resin comes increased strength. These elements and systems also have the advantage of a reduced gap at the resin-metal interface and therefore less susceptibility to deboned. ${ }^{(7)}$

The laser-etching surface treatment showed a significant difference in improving bond strength to a low fusing porcelain, as compared to acid-etching and machining surface treatment methods. The laser-etched surfaces demonstrated no significant difference in bond strength compared to airborneparticle- abrasion surfaces. ${ }^{(8)}$

Reyes et al. ${ }^{(9)}$ reported that hydrochloric acid treatment of the titanium substrate is an effective method for improving bond strength with low-fusing porcelain. Husaaini et al ${ }^{(10)}$ stated that airborneparticle abraded specimens showed greater bond strength than acid-etched specimens.

The bonding of resin to dental alloys has improved significantly over the last decade, and various bonding methods and techniques have been developed for base metal alloys, such as chemical etchant, and silica coating. The availability of adhesive primer for base metals that are capable of chemically bonding to a casting dental alloy has simplified the surface preparation of base metal alloys. ${ }^{(11)}$

Aims of the study: The aim of this study was evaluate metal roughness and share bond strength of chemical cured acrylic resin to chrom cobalt metal base after different surface treatment and metal primer (by hydrochloric acid, laser beam, and sand blasting)

\section{MATERIAL AND METHOD}

Shear bond strength:

Twenty five square plate forum samples were prepared by chrom cobalt alloy (bego company , Germany) and divided to five groups; (1)control (C), (2) coated with metal primer (Ivoclar Vivadent AG, Liechtensteinonly) applied for 180 second $(\mathrm{P})$ (manufacture instruction), (3) treated with laser beam and metal primer(LP) (50 watt, $20000 \mathrm{~Hz}$, pulsated laser), (4) acid etch (hydocloric acid $10 \% 30$ minutes then rinse with stream water )(8) with primer(AP), and (5) sand blast (for 30 second at 6 bar at $4.5 \mathrm{~cm}$ distance between nozzle and sample with aluminum oxide $125 \mu \mathrm{m})^{(13)}$ with primer (SP). the samples were fabricated from sheets of wax with $10 X 10 X 1 \mathrm{~mm}$ ( length $\mathrm{X}$ width $\mathrm{X}$ thickness respectively) . These square samples were sprued and invested in a phosphate-bonded investment (4 specimens in each ring), according to manufactures instruction. The alloys were melted in crucibles, the metal was melted in broken arm centrifuge using gas-oxygen torch. The sprue was removed using carbo-randum wheel. The specimens were finished with aluminum oxide stones (74 $\mu \mathrm{m}$ grit). Then, the side to which the acrylic resin was bonded further grinded with carbide bur in one direction and polished with rubber disks. ${ }^{(14)}$ After surface treatment of the polished surface that suggested for each group the cold cured acrylic resin(dentsply, Italy) were applied as follows: copper ring $5 \mathrm{~mm}$ in diameter and rubber piston to condense the resin dough $3 \mathrm{~mm}$ total thickness. The acrylic resin cylinder of each specimen was embedded in an acrylic resin cylinder using plastic ring to match the direction of the applied shear force. The metal was completely separated from the acrylic by a thin cellophane layer with an opening 
exposing the resin layer alone (Figure 1).

(12) The samples stored in $37 \mathrm{C}^{\circ}$ distilled water for 24 hours ${ }^{(15)}$, then The specimens were loaded to deboned by applying a shear force to the exposed metal part of the specimen as the resin part was

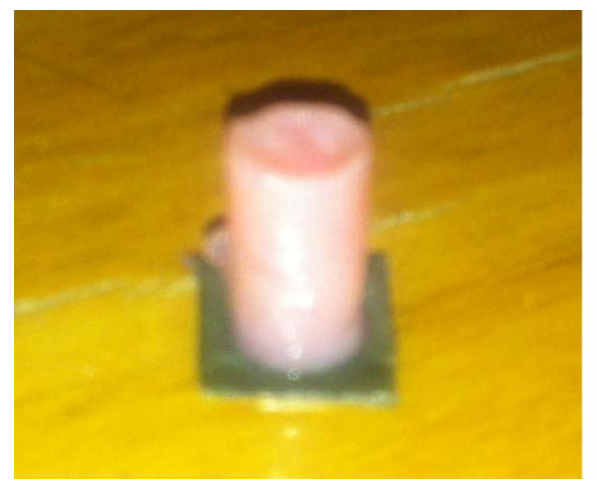

embedded in acrylic, until bond failure occurs. Shear bond strength was then measured with a universal testing machine (Digital Force Gauge, IMADA CO, Japan) at cross-head speed of $0.5 \mathrm{~mm} / \mathrm{min} .^{(16)}$

Shear strength $(\mathrm{MPa})=\mathrm{F} / \mathrm{A}$

Figure (1): Sample preparation for shear bond strength.

\section{Surface roughness test:}

Twenty five metal plate samples with 10X10X1 mm were prepared and finished and polished as mentioned for shear bond test then treated with different surface treatment ( C, P, LP, AP, and SP) in similar manner for shear bond test. then the treated surfaces were tested by profilemeter (Tylor-Hobson, England) in 3 different site for same sample to find the difference in surface roughness between the 4 treatment methods in contrast to control group, using the following parameters. ${ }^{(17)}$

Cut off: 2.5mm, and amplification: 5000, Roughness average.

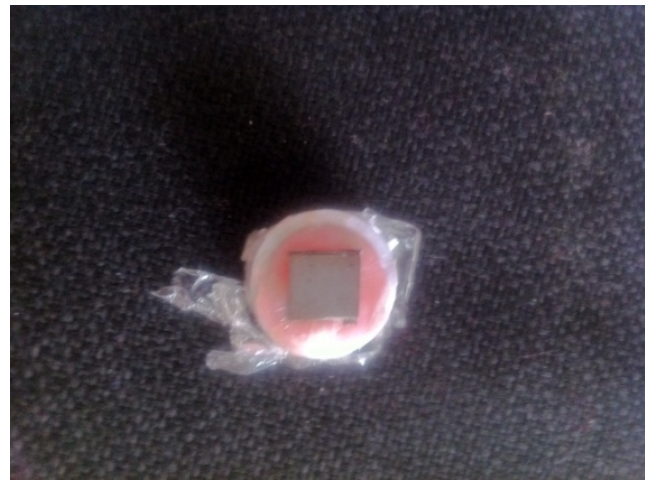

Mean, standard deviation, analysis of variance and Duncan's multiple rang test were carried out as statistical analysis for data by using SPSS statistical program.

\section{RESULT}

Table (1) showed mean and standard deviation of shear bond strength of acrylic resin with $\mathrm{Co}-\mathrm{Cr}$ metal plate, ANOVA (Table 2) demonstrated that there is a nificant differences $(\mathrm{P} \leq 0.05)$ in shear bond strength between different surface treatment groups of metal plate to bond with acrylic resin.

Table (1): mean and standard deviation of shear bond strength of acrylic resin with metal by different surface treatment.

\begin{tabular}{ccc}
\hline Variable & Number & Mean \pm SD(MPa) \\
\hline Control & 5 & $0.14 \pm 0.32$ \\
AP & 5 & $9.99 \pm 1.51$ \\
LP & 5 & $4.55 \pm 1.23$ \\
SP & 5 & $4.07 \pm 0.54$ \\
P & 5 & $4.79 \pm 0.75$ \\
\hline
\end{tabular}

AP: acid etch with metal primer; LP: laser beam with metal primer; SP: sandblast with metal primer; P: metal primer.

Table (2): ANOVA of bond strength of acrylic resin with metal by different surface treatment.

\begin{tabular}{cccccc}
\hline Source of variance & df & Sum of squares & Mean square & f-value & Significant \\
\hline Between groups & 4 & 243.539 & 60.88 & & \\
Within groups & 20 & 19.24 & 0.962 & 63.281 & 0.000 \\
Total & 24 & 262.78 & & & \\
\hline
\end{tabular}


Duncan's multiple rang test (Figure 2) revealed that all surface treatment groups had significant differences in relation to control group $(0.14 \pm 0.32 \mathrm{MPa})$, the HCL acid etch with metal primer (AP) had higher shear bond strength $(9.99 \pm 1.51$ $\mathrm{MPa}$ ) than other surface treatment of metal.

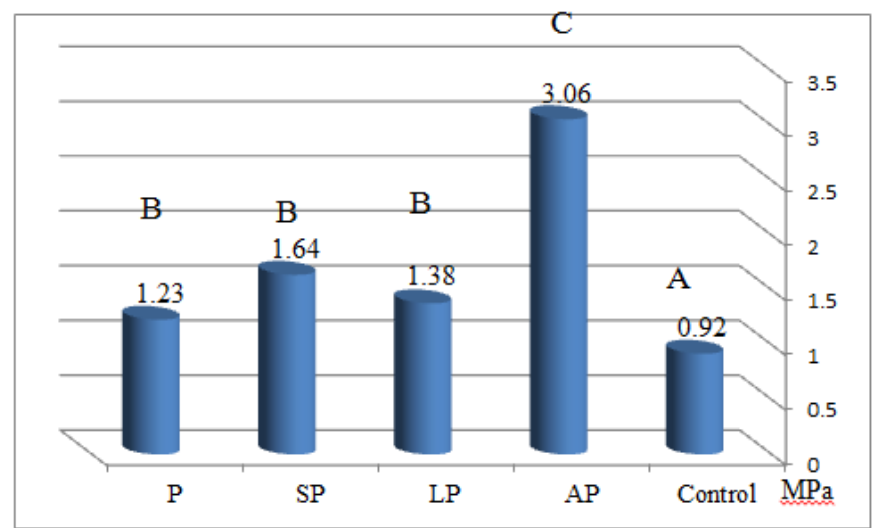

Figure (2): Duncan's Multiple range test of shear bond strength of acrylic resin with Co-Cr metal plate with acrylic resin.

AP: acid etch with metal primer; LP: laser beam with metal primer; SP: sandblast with metal primer; P: metal primer.

Table (3) showed the mean and standard deviation of surface roughness of metal surface with different surface treatments. Analysis of variance (Table 4) confirmed that there is significant differences between surface roughness of Co-Cr metal surface treated with different surface treatment.

Table (3): mean and standard deviation of surface roughness of Co-Cr metal

\begin{tabular}{ccc}
\multicolumn{3}{c}{ surface with different surface treatment } \\
\hline Variable & Number & Mean \pm SD $(\mu \mathrm{m})$ \\
\hline Control & 5 & $0.92 \pm .003$ \\
AP & 5 & $3.06 \pm 0.53$ \\
LP & 5 & $1.38 \pm 0.18$ \\
SP & 5 & $1.64 \pm 0.12$ \\
P & 5 & $1.23 \pm 0.09$ \\
\hline
\end{tabular}

AP: acid etch with metal primer; LP: laser beam with metal primer; SP: sandblast with metal primer; P: metal primer.

Table(4): ANOVA surface roughness of Co-Cr metal surface with different surface treatment

\begin{tabular}{cccccc}
\hline Source of variance & df & Sum of squares & Mean square & f-value & significant \\
\hline Between groups & 4 & 13.85 & 3.46 & & \\
Within groups & 20 & 1.39 & 0.07 & 49.69 & 0.000 \\
Total & 24 & 15.24 & & & \\
\hline
\end{tabular}

Figure (3) illustrated Duncan's multiple range test that showed there is higher surface roughness value of $\mathrm{Co}-\mathrm{Cr}$ surface $(3.06 \pm 0.53 \mu \mathrm{m})$ treated with HCL acid etch with metal primer in contrast with control $(0.92 \pm .003 \mu \mathrm{m})$ and other surface treatment. 


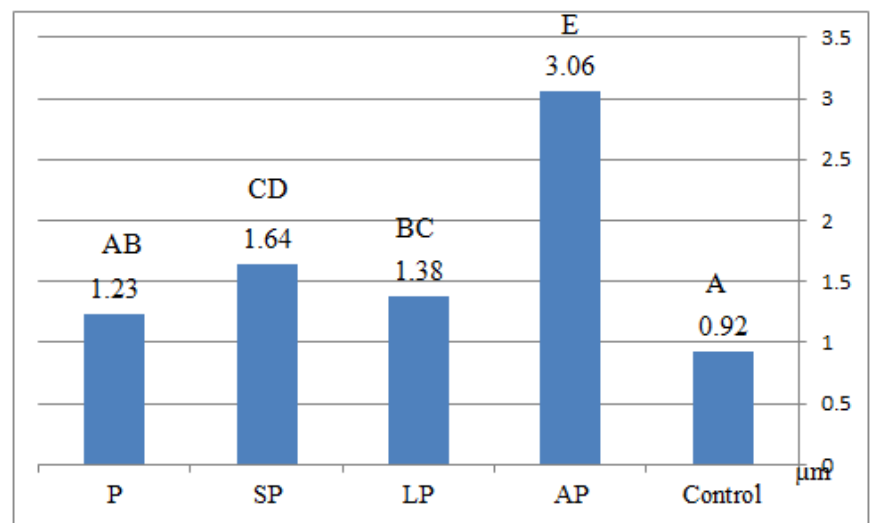

Figure (3): Duncan's Multiple range test of surface roughness of Co-Cr metal plate surface AP: acid etch with metal primer; LP: laser beam with metal primer; SP: sandblast with metal primer; P: metal primer.

\section{DISCUSSION}

Shear bond strength (SBS):

According to the results of this study, there is significant differences in mean shear bond strength between metal and acrylic resin that treated with different surface treatment such as AP, LP, SP, and $\mathrm{P}$ in contrast to control. Thus, the results support rejection of the first null hypothesis, which stated that the use of different adhesive primers would provide bond strength similar to that of the control group. ${ }^{(18)}$

According to the requirements of the revised ISO 10477, the minimum acceptable shear bond strength value is at least $5 \mathrm{MPa}{ }^{(19)}$

The bond strength of the acrylic resin and metal for control group $(0.14 \pm 0.32$ $\mathrm{MPa}$ ) is lesser than all other tested groups, AP(9.99 $\pm 1.51 \mathrm{MPa}), \mathrm{LP}(4.55 \pm 1.23 \mathrm{MPa})$ , $\mathrm{SP}(4.07 \pm 0.54 \mathrm{MPa})$ and $\mathrm{P}(4.79 \pm 0.75$ $\mathrm{MPa})$. It was reported that the bond strength was higher as the bonding surface became rougher. ${ }^{(20)}$ This differences in bond strength can be explained on the basis of differences in morphology. The use of hydrochloric acid produced microundercuts depend on the acid concentration and the composition of the material etched. $^{(21)}$

Sand blasting abrasion creates surface roughness by cleaning the surface of metal oxides and other substances and increases the mechanical and chemical bond strength between metal and acrylic re$\sin .{ }^{(22)}$ This result agree with Sarafianouetal which reported that Airborne-particle abrasion Al2O3 particles may result in improved bond strength, independent of the primer used ${ }^{(18)}$.

For metal plate with primer only the high shear bond strength (SBS) than control may be due to that the SBS of base metal alloy may depend on the thickness of the oxide layer and the surface roughness of the alloy surface ${ }^{(23)}$. This result agree with Kim etal ${ }^{(24)}$ which stated that metal primer increase SBS of metal to resin.

In case of LASER surface treatment the possible cause for high SBS in contrast to control group is the effect of surface etch and roughness by high energy power of laser $^{(8)}$. This result was agree with Gaggl et $\mathrm{al}^{(25)}$ reported that laser processing is a new method of treating implant surfaces to produce a high degree of purity with adequate surface roughness

\section{Surface roughness(SR):}

The result of this study showed that SR of all surface treatment was increased in relation to control group $(0.92 \pm .003 \mu \mathrm{m})$, in which the AP show significantly higher SR $(3.06 \pm 0.53 \mu \mathrm{m})$ this may be due to the effect of HCL acid which strong acid cause micro porous ${ }^{(21)}$ in addition to the effect of phosphoric acid that present in the composition of metal primer.

The sand blasting of metal plate had SR $(1.64 \pm 0.12 \mu \mathrm{m})$ which significantly differed from control group. This result may be due to the effect of pressurized aluminum oxide particles that not only affected the micromechanical roughening 
of the surface, but it left alumina particles embedded in the surface ${ }^{(26)}$. This is in agreement with Hofstede et al ${ }^{(27)}$, where the shot blasting treatment increases the implant surface roughness by the impingement, at high pressure, of small abrasive particles.

The metal plate with laser surface treatment show significant differences of SR $(1.38 \pm 0.18 \mu \mathrm{m})$ in compare to control this due to using a pulsed laser that remove small particles from a metal surface that carried out by laser beam using a selected area irradiation at an optimum combination of incident power, interaction/pulse time and gas flow rate. At the initial stage, a plasma plume is formed due to ionization of the atoms vaporized from the surface and blocks the beam-surface contact. As the irradiation stops, the temporary compression on the surface changes into tension and causes spallation of the oxidized layer. ${ }^{(28)}$

The SR of metal plate with metal primer only $(1.23 \pm 0.09 \mu \mathrm{m})$ had no significant difference contrast with control, although metal primer contain phosphoric acid in chemical structure but is not enough to cause micro porosity.

\section{CONCLUSIONS}

The use of hydrochloric acid with metal primer to Co-Cr metal increase surface roughness and shear bond strength to chemical cured acrylic resin.

Laser etching and sand blasting improve the roughness and bond resin to metal.

Using metal primer on metal surface alter surface roughness of this metal and slightly increase bond to acrylic resin. Chemical cured resin easily debond from $\mathrm{Co}-\mathrm{Cr}$ metal without using metal primer

\section{REFERENCES}

1. Mazurat RD, Pesun S. Resin-metal bonding systems: a review of the Silicoating and Kevloc systems. J Can Dent Assoc. 1998, 64(7):503-507.

2. Carr AB, Brown DT. McCracken's Removable Partial Prosthodontics,12th ed, Mosby, Inc., 2011.

3. Jacobson TE. The significance of adhesive denture base resin. Int $J$
Prosthodont 1989;2:163-72.

4. McConnell RJ. Metal-resin bonding. $J$ Can Dent Assoc J.1993;21:38-42

5. Jemt T, Linden B. Fixed ImplantSupported Prosfheses With Welded. Int J Periodont Res Dent .1992;12:177183.

6. Creugers NHJ, Snoek PA, van't Hof MA, Kayser AF. Clinical performance of resin-bonded bridges: a five year prospective study. Part III: Failure characteristics and survival after rebonding. J Oral Rehabil .1990; 17:179-186

7. Pesun S, Mazurat RD. Bond strength of acrylic resin to cobalt-chromium alloy treated with the silicoater md and kevloc systems . J Can Dent Assoc. 1998;64(11):798-802

8. Kim JT, Cho SM. The effects of laser etching on shear bond strength at the titanium ceramic interface. $J$ Prosthet Dent 2009;101:101-106.

9. Reyes MJ, Oshida Y, Andres CJ, Barco T, Hovijitra S, Brown D. Titaniumporcelain system. Part III: effects of surface modification on bond strengths. Biomed Mater Eng . 2001; 11:117-136.

10.Al Hussaini I, Al Wazzan KA. Effect of surface treatment on bond strength of low-fusing porcelain to commercialy pure titanium. J Prosthet Dent. 2005; 94:350-6.

11.Kim SS, Vang MS, Yang HS, Park SW, Lim HP . Effect of adhesive primers on bonding strength of heat cure denture base resin to cast titanium and cobalt-chromium alloy. J Adv Prosthodont. 2009; 1:41-46.IVSL.

12.Kharoofa EM. The effect of using recasted metal on castebility and shear bond strength of porcelain- fused to $\mathrm{Ni}-\mathrm{Cr}$ casting alloys. MSc thesis. College of dentistry. University of Mosul. 2008.

13.Hofstede TM, Ercoli C, Graser GN, Tallents RH, Moss ME, Zero DT. Influence of metal surface finishing on porcelain porosity and beam failure loads at the metal-ceramic interface. $J$ Prosthet Dent. 2000; 84:309-317.

14.Anusavice KJ. Phillips' science of dental materials. Philadelphia: WB. Saunders; 1996. p. 594-605.

15. NaBadalung DP, Powers JM, Connelly ME. Comparison of bond strengths of 
denture base resins to nickelchromiumberyllium removable partial denture alloy. J Prosthet Dent. 1997;78(6):56673.

16.Ceftici Y, Canay S, Hersek N. Shear bond strength evaluation of different veneering system on $\mathrm{Ni}-\mathrm{Cr}$ alloys. J.Prosthodon. 2007; 16:31-36.

17.Al-Ni'aimi AJ. The Effect of Laser Welding on the Tensile Strength and Radiographic Analysis of $\mathrm{Co}-\mathrm{Cr}$ Repaired Joints. MSc thesis. College of dentistry. University of mosul. 2008

18. Sarafianou A, Seimenis I, Papadopoulos T. Effectiveness of different adhesive primers on the bond strength between an indirect composite resin and a base metal alloy. $J$ Prosthet Dent. 2008;99:377-387.

19.ISO10477:2004. Dentistry-polymerbased crown and bridge materials. International Organization for Standardization. Geneva, Switzerland. Available at www.iso.org/iso/store.htm.

20.Kurtz K, Kabcenell J, Watanabe I, Okabe T. Shear bond strength of polymer- glass to cast titanium. $J$ Dent Res .1998;77:272.

21.Özcan M, Alkumru HN, Gemalmaz D. The Effect of Surface Treatment on the Shear Bond Strength of Luting Cement to a lass- Infiltrated Alumina Ceramic. Int J Prosthodont. 2001;14:335-339.

22. Rothfuss LG, Hokett SD, HondrumSO,
Elrod VW. Resin to metal bond strengths using two commercial systems. J Prosthet Dent 1998;79:270272.

23.Powers JM, Sakaguchi RL. Craig's Restorative Dental Materials. 12th ed. St. Louis Elsevier. 2006.

24.Kim JY, Pfeiffer P, Niedermeier W. Effect of laboratory procedures and thermocycling on the shear bond strength of resin metal bonding systems. J Prosthet Dent. 2003;90: 184-9.

25.Gaggl A, Schultes G, Müller WD, Kärcher. H. Scanning electron microscopical analysis of laser-treated titanium implant surfaces-a comparative study. Biomaterials. 2000;21:1067-73.

26.Fujishima A, Miyazaki T, Fujishima Y, Shiba A. Influence of sandblasting treatment with several alumina particles on the surface texture of CP titanium. J Jpn Dent Mater.1997;16:21826.

27.Hofstede TM, Ercoli C, Graser GN, Tallents RH, Moss ME, Zero DT. Influence of metal surface finishing on porcelain porosity and beam failure loads at the metal-ceramic interface. $J$ Prosthet Dent; 2000 84:309-317.

28. Majumdar J, Manna I. Laser processing of materials. Sadhana; 2003.28; 495562 